\title{
The relationship of Attitude with the compliance of Midwives in the prevention of infection in Aid Delivery in Balangan Hospital
}

\author{
$1^{\text {st }}$ Istiqamah $^{1}, 2^{\text {nd }}$ Elvine Ivana Kabuhung ${ }^{2}$ \\ \{istiqamah25@yahoo.co.id $\left.{ }^{1}\right\}$ \\ ${ }^{1}$ Program Studi S1 Kebidanan Universitas Sari Mulia \\ ${ }^{2}$ Program Studi S1 Kebidanan Universitas Sari Mulia \\ *correspondence author: Telepon: +6281251271933, E-mail: \\ istiqamah25@yahoo.co.id
}

\begin{abstract}
The purpose of the study to know the attitude to the compliance of midwives in preventing infection in childbirth aid in Balangan hospital. This study used Analytical surveys with cross-sectional approaches. The sampling way in this study was conducted with total sampling. The results showed that a positive attitude is $56.7 \%$ and negative attitude is $43.3 \%$ while complying with $66.7 \%$ and not complying with $33.3 \%$. Analyzed with Chi-Square test obtained the result that the value $\mathrm{p}=0.045<0.05$. There is a relationship between the attitude with midwives ' compliance in preventing infection in childbirth relief.
\end{abstract}

Keywords: attitude, midwives, prevention of infection.

\section{Introduction}

Delivery assistance by health workers (doctors and midwives) is one of the risk factors for transmission of the disease from patients to health workers or vice versa because it is directly related to the patient's body fluids. Considering that infections are transmitted through blood, vaginal secretions, semen, amniotic fluid and other bodily fluids, any officer working in an environment that may be exposed to these risks has the risk of contracting if he does not heed infection prevention procedures [11].

Data on the profile of the South Kalimantan provincial health service in 2015 the number of HIV cases increased from 2010 which was only 144 cases to 284 cases up to 2015 , while the number of hepatitis B cases is estimated to double by 2 where South Kalimantan is among the regions with the above prevalence rates average. In the town of Balangan itself in 2014 there was the death of 1 mother who was caused due to infection at the time after delivery.

On August 2-3 in 2017, researchers conducted a preliminary study with 4 midwives of independent practice and found that they knew the theory about the importance of infection prevention but because their habits in the field were not in accordance with the standard operational procedures (SOP) for infection prevention which should be like washing hands, using a personal protection device consisting of gloves, masks, headgear, aprons, glasses, and 
boots. They feel lazy, feel uncomfortable and bothered, generally they help deliveries wearing PPE that is incomplete, some only wear flip-flops when helping with labor.

Based on the background of the problem, researchers are interested in conducting further research on "Relationship between attitude and midwife adherence in the prevention of infection in childbirth assistance at Balangan Regional Hospital"

\section{Materials And Methods}

This research is an analytic survey research with cross sectional approach. The population of this study were all midwives who assisted deliveries in the delivery room at Balangan Regional Hospital with a total of 30 people. The sampling technique used in this study is total sampling in which all populations are sampled. Samples taken were midwives who assisted deliveries in the delivery room of Balangan Hospital as many as 30 respondents.

\section{Result}

a. Univariate analysis

This research was conducted based on the results of the questionnaire and observation sheets distributed to respondents in the maternity Room of Balangan Regional Hospital.

The following is presented to illustrate the distribution and percentage of each variable presented in the following tables:

Table 1. Frequency distribution of respondents based on the attitude of midwives in the working area of Balangan Regional Hospital

\begin{tabular}{lll}
\hline \multicolumn{1}{c}{ attitude } & Frequensi & Percentase \\
\hline Positif & 17 & 56,7 \\
\hline Negatif & 13 & 43,3 \\
\hline Total & & \\
\hline
\end{tabular}

Based on table 1, it can be seen that the attitude of midwives in preventing infection in delivery assistance at Balangan Regional Hospital is positive attitude as many as 17 people $(56,7 \%)$, and negative attitude as much as 13 people $(43,3 \%)$. 
Table 2. Frequency distribution of midwives' attitudes based on education in the work area Balangan Hospital

\begin{tabular}{cccccccc}
\hline \multirow{3}{*}{ education } & \multicolumn{3}{c}{ Attitude } & \multicolumn{2}{c}{ total } \\
\cline { 2 - 7 } & $\mathrm{F}$ & Positif & $\%$ & $\mathrm{~F}$ & $\%$ & $\mathrm{~F}$ & $\%$ \\
\cline { 2 - 7 } & 15 & 50 & 12 & 40 & 27 & 90 \\
D3 & 2 & 6,7 & 1 & 3,3 & 3 & 10 \\
\hline bachelor & 17 & 56,7 & 13 & 43,3 & 30 & 100 \\
\hline total & 17 &
\end{tabular}

Based on Table 2 it can be seen that of the 30 respondents the most positive attitude was based on education namely the respondents with D3 education background were 15 people $(50 \%)$ while the least were negative attitudes namely respondents with educational background were 1 org $(3,3 \%)$

Table 3. Frequency distribution of midwives' attitudes based on work in the Balangan Regional Hospital

\begin{tabular}{|c|c|c|c|c|c|c|c|}
\hline \multicolumn{8}{|c|}{ attitude } \\
\hline & work & positif & & negatif & & total & \\
\hline & $f$ & $\%$ & $\mathrm{f}$ & $\%$ & $\mathrm{f}$ & $\%$ & \\
\hline 1 & $\begin{array}{c}\text { Government } \\
\text { employes }\end{array}$ & 10 & 33,4 & 1 & 3,3 & 11 & 36,7 \\
\hline 2 & $\begin{array}{l}\text { Temporary } \\
\text { employes }\end{array}$ & 7 & 23,3 & 12 & 40 & 19 & 63,3 \\
\hline total & & 17 & 56,7 & 13 & 43,3 & 30 & 100 \\
\hline
\end{tabular}

Based on table 3 it can be seen that of the 30 most respondents who were negative by occupation ie respondents with PTT work amounted to 12 people $(40 \%)$ and the least were respondents who behaved positively based on work ie respondents with PTT work numbered 7 people $(23,3 \%)$.

Table 4. Distribution of respondents' frequency based on midwife's compliance in preventing infection in childbirth assistance in the working area of Balangan Regional Hospital

\begin{tabular}{ccc}
\hline obedience & Frequensi & Percentase \\
\hline obedient & 20 & 66,7 \\
Not obey & 10 & 33,3 \\
\hline Total & 30 & 100 \\
\hline
\end{tabular}

Based on Table 4, it can be seen that midwives' compliance in preventing infection in delivery assistance at Balangan Regional Hospital is 20 people $(66,7 \%)$ obedient, and 10 people $(33,3 \%)$ disobedient. 
Table 5. Distribution of midwife compliance by education in the working area of Balangan Hospital

\begin{tabular}{cccccccc}
\hline & \multicolumn{7}{c}{ obedience } \\
\hline \multirow{2}{*}{ no } & Education & obedient & & Not obey & & total \\
\cline { 3 - 8 } & & $\mathrm{F}$ & $\%$ & $\mathrm{~F}$ & $\%$ & $\mathrm{~F}$ & $\%$ \\
\hline 1 & 17 & 56,6 & 10 & 33,4 & 27 & 90 \\
2 & bachelor & 3 & 10 & 0 & 0 & 3 & 10 \\
\hline & total & 20 & 66,6 & 10 & 43,4 & 30 & 100 \\
\hline
\end{tabular}

Based on Table 5 it can be seen that of the 30 respondents who most carried out adherence in the prevention of infection based on education namely Obedient numbered 17 people $(56,6 \%)$ with a D3 background, while Non-Obedient numbered at least 10 people $(33,4 \%)$ with an educational background.

Table 6. Distribution of frequency of midwife compliance based on work in the working area of Balangan District Hospital

\begin{tabular}{cccccccc}
\hline & & \multicolumn{3}{c}{ obedience } \\
\cline { 3 - 7 } no & ocupation & \multicolumn{2}{c}{ obedient } & \multicolumn{2}{c}{ Not obey } & \multicolumn{2}{c}{ total } \\
\hline 1 & F & $\%$ & F & $\%$ & F & $\%$ \\
\hline 2 & $\begin{array}{c}\text { Government } \\
\text { employes } \\
\text { Temporary } \\
\text { employes }\end{array}$ & 9 & 30 & 2 & 6,6 & 11 & 36,6 \\
\hline total & 11 & 36,7 & 8 & 26,7 & 19 & 63,4 \\
\hline
\end{tabular}

Based on Table 6 it can be seen that of the 30 most respondents who were Obedient by Occupation ie respondents with PTT work totaling 11 people $(36,7 \%)$ and the least were respondents who were not compliant by occupation ie respondents with PNS jobs amounted to 2 people $(6,6 \%)$.

b. Bivariat Analysis

Research analysis using Chi square test, the research results are obtained based on the following categories : 
Table 7. Relationship between Midwives' Attitudes and Compliance in Prevention of Infection in Labor

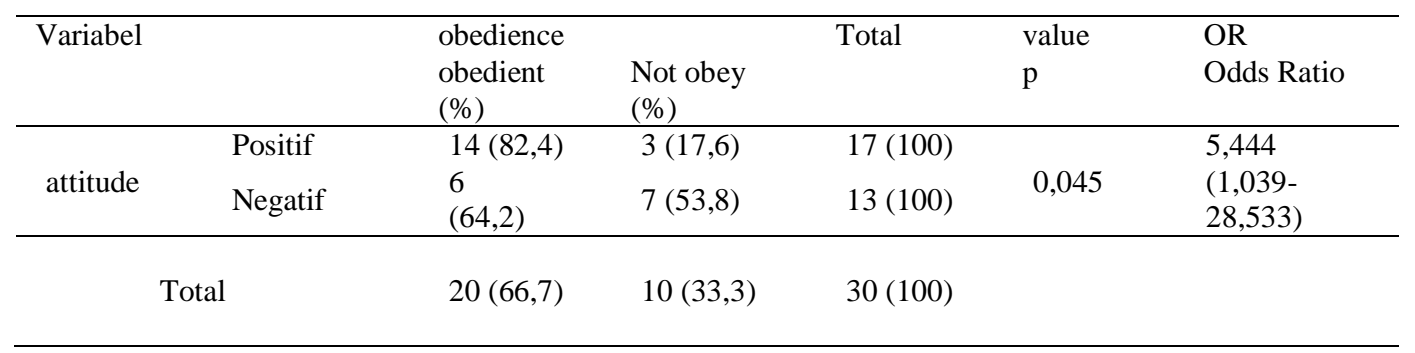

Based on table 7. obtained the results of an analysis of the attitude of midwives with midwife compliance in the prevention of infection in labor obtained $p=0.045$ with an OR value of 5.444. So it can be concluded that there is a significant relationship between Midwife Attitudes and Compliance in the prevention of infection in childbirth in hospitals. Balangan, where midwives who are positive tend to be 5.4 times more likely to have compliance in carrying out prevention of infection in labor compared with midwives who are negative.

\section{Discussion}

1. Midwife's attitude in preventing infection in childbirth at Balangan Regional Hospital

Based on the results of the study note that of 30 respondents as many as 17 midwives $(56,7 \%)$ have a positive attitude and as many as 13 midwives $(43,3 \%)$ have a negative attitude.

A midwife's attitude is said to be good if they dare to take responsibility for the risks of the decisions they make. Generally midwives already have the right knowledge about infection prevention, especially in the aid of normal childbirth. At the midwife in hospital. The average Balangan has a positive attitude and has a fairly high level of responsibility, this can be seen from the midwife's answer to item (1) which states that the implementation of prevention measures infection with a systematic and correct is very important when giving birth assistance.

This is in line with the results of Rahmona's (2014) study which states that the meaning of the relationship between midwives' attitudes and behavior in preventing the risk of HIV / AIDS transmission in childbirth assistance shows that midwives who behave positively have more good behavior,

Likewise, midwives whose attitudes were negative in the attitude they showed were also of poor value $\mathrm{p}=0.004(\mathrm{p}<0,05)$

A person's attitude is determined by knowledge, because knowledge contains two aspects, namely positive aspects and negative aspects. Both of these aspects will determine a person's attitude, the more positive aspects such as the benefits of carrying out infection prevention and the negative aspects of the impact of not implementing infection prevention, the more positive attitude will result. This is consistent with the opinion of which states that the highest level of attitude is to be responsible for what he believes. Someone who has taken a certain attitude based on his belief must be brave to take risks[9]

However, there are still some midwives who still have a negative attitude, especially in item (3) regarding "Prevention of infection during labor delivery causes a lot of time wasted on patients and their families while not providing meaningful protection for the health of 
midwives", this is contrary to the task midwives who should have health behaviors related to illness and disease for the realization of midwives' awareness to improve the quality of services better by paying attention to aspects of human behavior, one of which is an internal factor in the midwife itself. An attitude has not automatically manifested in an overt behavior because other factors also influence such as the availability of facilities, support from superiors / professional organizations or environmental situations that do not allow according to the attitude of a health worker in providing services to the community must be based on the will, motivation and also must be based on professional ethical principles, so that health workers can face challenges and can carry out their duties properly[10].

2. Midwife compliance in preventing infection in childbirth at Balangan Regional Hospital

Based on the results of research on the relationship between midwives' attitudes and adherence in preventing infection in childbirth assistance, the results of the analysis were obtained using the chi square test $\mathrm{p}=0.045$ and $\mathrm{OR}=5.444$. So it can be concluded that there is a significant relationship between the attitude of midwives with compliance in carrying out prevention of infection in childbirth, where midwives who have a positive attitude tend to have compliance 5.4 times greater in carrying out prevention of infection in labor compared with negative attitude of midwives.

According to the results of the study although there are some midwives who have negative attitudes seen in the items regarding "Wearing glasses and masks when giving birth help will provide protection against exposure to mucous membranes" this occurs generally due to the unavailability of facilities by the hospital, midwives also feel not accustomed and disturbed and they consider harmless even if they do not use the equipment. This is according to the observation results due to lack of facilities, inadequate personal protective equipment, and other things according to the researchers' assumptions because midwives feel lazy, feel uncomfortable and feel bothered when using personal protective equipment, even though these reasons will adversely affect midwives as health workers and patients.

In connection with work that is regulated in the SOP, the attitude value of health workers must be focused on positive values in order to support the services provided, according to the Ministry of Health (2008) which states that normal childbirth care is strived to maintain survival and provide a degree of health that is high for mothers and infants through integrated and complete efforts with minimal intervention for the principle of safety and the level of quality of care that is maintained at an optimal level.

A person's attitude is determined by knowledge, because knowledge contains 2 aspects, namely positive and negative. Both of these aspects will determine a person's attitude, the more positive aspects such as knowing the prevention of infection in labor, it will lead to midwife compliance. According to Allport in Notoatmodjo (2007) attitude consists of 3 main components namely belief or belief, emotional life and tendency to act. the three components together form a holistic attitude[9].

The results of this study are), which states that there is a significant relationship between knowledge and Nakes attitude about infection prevention in childbirth assistance $\mathrm{p}=0,000$ ( $\mathrm{p}$ $<0.05)$. This attitude is related to knowledge and actions in individual behavior factors. This attitude is a continuation of the individual to carry out a stimulus in this case the problem of compliance with infection prevention and attitude indicators[9].

According to the researcher, it can be explained that the majority of respondents educated in midwifery diploma (D3 midwifery) are included in the higher education standard, namely the higher the level of education, the easier it is for someone to receive information so 
that it increasingly influences the attitude and compliance of the midwife. Factors that influence the positive attitude and compliance of respondents due to the majority of respondents aged $>35$ years.

In line with the theory of which states that the more a person's age increases, the maturation of organ functions in psychological or mental aspects of a person's level of thinking becomes more mature and mature.[9]

that the formation of attitudes can be influenced by the level of one's education where the higher one's education the easier it is to absorb the information provided other than because of personal experience that makes someone know how to behave.[3]

According to attitude is a closed reaction or response from someone to an stimulation or object that allows for an action or behavior to arise. Many factors affect a person's attitude including the level of education, socioeconomic, environmental influences and the influence of personality and experience factors[9].

\section{Acknowledgment}

I thank those who dr. Fery, MM, as a director have given permission and the opportunity to do research in the Balangan hospital.

\section{References}

[1]. Aziz Alimul Hidayat. Quantitative Paradigm Health Research Methods. Surabaya: Health books publishing (2010).

[2]. Anik Maryunani. Prevention of Infections in Midwifery. Jakarta: PT Trans Info Media (2011).

[3]. Azwar, Saifuddin. The Human Attitude Theory And Its Measurement. Yogyakarta: Pustaka Pelajar (2013).

[4]. Indrayani. Childbirth and newborn care, Edwin, Editor. Jakarta:PT Trans Info Media (2013).

[5]. Jaringan Nasional Pelatihan Klinik (JNPK-KR) Normal childbirth care. Jakarta (2008).

[6]. Kemenkes RI. Laporan Hasil Riset Kesehatan Dasar (RISKEDAS) Nasional 2013. Jakarta: Health Research and Development Agency (2014).

[7]. Mardianti. Factors Associated with Midwife Compliance in Prevention of Infection in Childbirth Assistance at the Health Center Level Kabupaten Karawang. (Skripsi) Dosen Non Fungsional Prodi Kebidanan Karawang Poltekkes Bandung (2013).

[8]. Magdalena. The relationship of knowledge about the risk of workplace accidents and the behavior of using personal protective equipment to nurses at the hospital Puri Mandiri Kedoya (2013).

[9]. Notoatmodjo soekidjo. Health Behavioral Sciences Jakarta: Rineka Cipta (2010).

[10]. Nursalam. Concept and Application of Nursing Research Methodology Pedoman Skripsi, Tesis, and Nursing Research Instruments. Jakarta: Salemba Medika. (2013).

[11]. Saifuddin. Midwifery. Jakarta: PT Bina Pustaka Sarwono Prawiroharjo (2010). 